\title{
ACESSO À JUSTIÇA E O SISTEMA PRISIONAL NO BRASIL
}

\author{
José Valente Neto* \\ Jânio Pereira da Cunha*
}

Resumo: $O$ artigo analisa o acesso à justiça e o sistema penal no Brasil. Almeja-se, especificamente, investigar a compatibilidade entre o Estado democrático de Direito, reinaugurado com a Constituição de 1988, e o direito de acesso à justiça criminal. O método de pesquisa empregado foi o bibliográfico e de aferição de dados publicados em sítios oficiais. Os resultados indicam o crescente aumento no número de presos. Concluiu-se, então, que o acesso à justiça precisa avançar para a consolidação da democracia e que a justiça, ao prender e condenar, em sua maioria, negros e pobres, atua de maneira autoritária e seletiva.

Palavras-chave: Acesso à justiça. Prisão. Inconstitucionalidade. Estado. Democracia.

\section{ACCESS TO JUSTICE AND THE PRISON SYSTEM IN BRAZIL}

Abstract: The article analyzes access to justice and the penal system in Brazil. It specifically aims to investigate the compatibility between the democratic rule of law, reopened with the 1988 Constitution, and the right of access to criminal justice. The research method used was the bibliographic and the measurement of data published in official sites. The results indicate the growing increase in the number of prisoners. It was concluded, then, that access to justice needs to move towards the consolidation of democracy and that justice, by arresting and condemning mostly black and poor, acts in a way authoritarian and selective.

Keywords: Access to justice. Prison. Unconstitutional.State. Democracy.

\section{Introdução}

$\mathrm{O}$ artigo tem como objetivo analisar o grau de efetividade do direito de acesso à justiça criminal no Brasil. Almeja-se, precipuamente, responder a três perguntas: i) o estágio de eficácia do acesso à justiça é compatível com a democracia?; ii) na hipótese de incompatibilidade, quais são as causas?; e iii) é possível a identificação de uma categoria específica de pessoas no cárcere? Para tanto, a abordagem se concentrará em dois aspectos: as prisões cautelares e o princípio da presunção de inocência. Apesar de uma pluralidade de

\footnotetext{
* Doutorando em Direito pela Universidade Federal do Ceará (UFC). Mestre em Direito pela Universidade de Fortaleza (UNIFOR). Defensor Público do Estado do Ceará. Endereço: Rua 8 de setembro, 1130, apto. 2102, Varjota, Fortaleza-CE, CEP: 60.175-210. Email: josevalenteneto1979@ gmail.com.

* Professor do Curso de Direito e do Programa de Pós-Graduação em Direito (Mestrado Acadêmico) do Centro Universitário Christus (UNICHRISTUS). Professor do Curso de Direito da Universidade de Fortaleza (UNIFOR). Doutor em Direito Constitucional (UNIFOR). Endereço: Rua 8 de setembro, 1130, apto. 701, Varjota, Fortaleza-CE, CEP: 60.175-210. Email: janiopcunha@ hotmail.com.

CONPEDI LAW REVIEW | EVENTO VIRTUAL | v. 6 | n. 1 | p. 196 - 215 | JAN - DEZ | 2020 
questões exploráveis, estes pontos traduzem os elementos mais relevantes do sistema prisional.

Além da importância de se revisitar o princípio constitucional do devido processo legal, o reconhecimento, na Ação de Descumprimento de Preceito Fundamental 347, das prisões como cenário de violação generalizada de direitos humanos, reclama reflexões e conclama alternativas. No bojo desta discussão, pretende-se resgatar aspectos históricos a fim de formular um parecer sobre o problema da pena privativa de liberdade e suas sequelas na consolidação de um Estado Democrático de Direito. O método de pesquisa empregado foi o bibliográfico, por meio da leitura de livros e artigos científicos, assim como a aferição de dados publicados em sítios oficiais sobre a realidade do sistema penal no Brasil.

O recrudescimento da insegurança pública é tema recorrente na agenda política no Brasil. Embora se trate de um fenômeno histórico, as três décadas pretéritas, coincidentes com a redemocratização, representam um paradoxo em virtude do crescimento vertiginoso das estatísticas carcerárias.

Nesta conjuntura, os três anos precedentes são singulares: i) 2016: o impeachment da presidenta da República e a Lei 13.260, a qual disciplina o crime de terrorismo, e o julgamento do Habeas Corpus 126.292/SP pelo Plenário do Supremo Tribunal Federal, segundo o qual é possível a execução provisória de acórdão penal condenatório antes do trânsito em julgado ${ }^{1}$; ii) 2017: a primeira vez que um presidente foi denunciado criminalmente no exercício da função e, de forma inédita, o advento de uma sentença condenatória de um expresidente da República por crime comum; iii) 2018: decreto 9.288, expediente para a intervenção federal no Rio de Janeiro, primeiro ato excepcional pós-1988, prisão de um expresidente da República e eleição de um presidente que defende o ultraliberalismo na economia e o conservadorismo moral pertinentes às questões cultural, educacional e religiosa, assim como familiar, reprodutiva, sexual e de gênero. (LACERDA, 2019).

\section{Evolução do direito de acesso à justiça criminal no Brasil}

O modelo de colonização português foi exitoso, entre outros fatores, em face da outorga de um sistema penal rigoroso composto por uma coletânea de normas esparsas e pelas

\footnotetext{
${ }^{1}$ Em 7 de novembro de 2019, o Plenário do Supremo Tribunal Federal, por maioria (6 x 5), decidiu que é constitucional a regra do Código de Processo Penal (CPP) que prevê o esgotamento de todas as possibilidades de recurso (trânsito em julgado da condenação) para o início do cumprimento da pena. (BRASIL, 2019).
} 
Ordenações do Reino. Com efeito, “as formações sociais escravistas tornaram-se organizações político-econômicas altamente articuladas, com os seus centros de poder, princípios e procedimentos de mando e execução, técnicas de controle e repressão." (IANNI, 1978, p. 11). A escravidão, em grande medida, era baseada no terror e na ameaça.

Em regra, a segregação e a discricionariedade foram a tônica entre os séculos XVI e XVIII. Os negros foram os principais alvos da violência; nas senzalas, no eito, no pelourinho, o pau e o chicote grassaram impiedosamente. "No Brasil, costumam dizer que para o escravo são necessários três PPP, a saber, pau, pão e pano." (ANTONIL, 2011, p. 108). Os tumbeiros tinham um propósito específico, pois em relação aos escravos "nada mais se queria dele, e nada mais se pediu e obteve que a sua força bruta, material. Esforço muscular primário, sob a direção e açoite do feitor." (PRADO JÚNIOR, 2000, p. 280). A propósito, consoante a crítica de Nilo Batista,

\begin{abstract}
quem ficar apenas nos textos legais nunca saberá do que realmente se passou. As Ordenações, por ora Manuelinas e a partir do início do século XVII Filipinas, são apenas um pano de fundo para um exercício pouco regulamentado, e às vezes desregulamentado, do poder punitivo. Aos donatários delegava o rei poder punitivo. $\mathrm{Na}$ carta através da qual Duarte Coelho se imitia no governo do que seria Pernambuco, sua jurisdição criminal tinha alçada até a pena de morte - para escravos, índios e livres pobres ('peões cristãos homens livres') - e até dez anos de degredo ou cem cruzados para 'pessoas de mor qualidade', salvo naturalmente os casos de heresia, traição, sodomia e moeda falsa, nos quais o poder punitivo represado para a constituição dos estados nacionais precisava romper os estatutos pessoais privilegiados. $(2002$, p. 150$)$.
\end{abstract}

No período das capitanias hereditárias, o direito ficou sob a incumbência dos senhores ou ouvidores, nem sempre letrados; na prática, pelo menos nas primeiras décadas, "era quase o arbítrio dos donatários." (PIERANGELLI, 1983, p. 63). Este arquétipo foi paulatinamente sendo objeto de alterações nas etapas subsequentes da ocupação portuguesa. À medida em que a burocracia ia se constituindo e se ramificando, a estrutura e a estratificação social eram moldadas a fim de realizar, em sua plenitude, a empresa açucareira e, posteriormente, mineradora.

Não se olvida, entretanto, que muitos escravos foram sujeitos da própria história. Além de participarem de negócios e de se tornarem senhores e proprietários de escravos, vários deles provocaram o Poder Judiciário a fim de defenderem os seus direitos, inclusive o de não serem reescravizados. Um dos primeiros livros publicados no Brasil que tinha como perspectiva romper a historiografia tradicional no sentido de que os escravos sempre tiveram 
um comportamento passivo e que foram tratados como coisas é o de Kátia Mattoso, cuja primeira edição é de 1982:

Não se deve esquecer tampouco que esses senhores nem sempre são brancos e por vezes nem mesmo homens livres. Com efeito, desde bem cedo dois movimentos caracterizaram a sociedade brasileira: a mestiçagem e a manumissão conferem originalidade ao Brasil dos séculos XVII, XVIII e XIX. Mestiçagem e manumissão, sinais de mobilidade social, são ambas extremamente frequentes. (2003, p. 132).

Trata-se de um dos pontos de vista sobre o fenômeno complexo não apenas da sociedade colonial e imperial, mas da escravidão como um todo. A relativização de alguns aspectos da escravidão empregada pela historiadora recebeu, por outro lado, uma crítica de Jacob Gorender:

A obra recente de Kátia de Queirós Mattoso se insere nesta linha de concepção do
escravismo patriarcal. Escravos domésticos e escravos do eito são abrigados e
condicionados em sua personalidade pela mesma instituição básica do sistema - a
família do senhor. A autora, por isso mesmo, dá maior ênfase aos mecanismos de
adaptação e ajustamento do escravo do que às tendências à contradição e ao conflito.
Daí também a insistência com que ressalta a criatividade do escravo brasileiro no
sentido da adaptação, enquanto ficam em segundo plano as manifestações de
antagonismo ao sistema que o oprime e explora. (2010, p. 309).

A jurisdição criminal era ampla e irrestrita, uma vez que englobava até a pena capital, suscetível a clemência. Consoante os registros de Euclydes da Cunha, "o Brasil era a terra do exílio; vasto presídio com que se amedrontavam os heréticos e os relapsos.” (2000, p. 78). O cenário de terror e de temor colocava os cativos em condição singular: "O escravo era encarado, desde o direito romano, como um inimigo: inimigo doméstico, justificando a seu respeito uma legislação de exceção, e um inimigo público, sempre pronto a rebelar-se.” (1976, p. 52, v. I). Para A. J. R. Russell-Wood,

No nível local, a justiça para os libertos de cor era arbitrária e, frequentemente, violenta. Havia um conjunto de leis e punições para brancos e outro para pessoas de cor. Um edito promulgado pelo governador de São Paulo em 27 de março de 1732 contra o contrabando de ouro previa as penas de banimento para Angola e multa de 2.000 cruzados para acusados brancos, enquanto negros livres, mulatos e ameríndios também seriam banidos mas, além disso, receberiam quatrocentas chicotadas. (2005, p. 108-109).

Na mesma linha de cognição, Charles R. Boxer afirmou que "há uma grande quantidade de provas que contrariam a moderna posição portuguesa de que o Brasil foi um caso em que não houve derramamento de sangue.” (2017, p. 104). Por outro lado, na perspectiva de que a Coroa enfrentou várias dificuldades e condicionalismos, António Manuel Botelho Hespanha defende que o sistema penal da monarquia corporativa não estava voltado para uma intervenção punitiva quotidiana e efetiva: 
De fato, a função político-social determinante do direito penal real não parece ser, na sociedade "sem Estado" dos séculos XVI e XVII, a de realizar, por si mesmo, uma disciplina social. Para isso lhe falta tudo - os meios institucionais, os meios humanos, o domínio efetivo do espaço e, por fim, o domínio do próprio aparelho de justiça, expropriado ou pelo "comunitarismo" das justiças populares ou pelo "corporativismo" dos juristas letrados. A função da punição parece ser, em contrapartida, a de afirmar, também aqui, o sumo poder do rei como dispensador, tanto da justiça como da graça. É nesta perspectiva que, a meu ver, deve ser lido o direito penal da coroa. Feita esta leitura, não deixaremos de convir que, em termos de normação e punição efetiva, o direito penal se caracteriza, mais do que por uma presença, por uma ausência. (2012, p. 134). ${ }^{2}$

Em termos político-religiosos, uma época de obscurantismo, exploração e perseguição; em sentido jurídico propriamente dito, um tributo à inquisição, pois a obtenção das provas ou, com demasiada frequência, de meros indícios, ocorriam pelo uso de expedientes perversos, quase letais, como a tortura. Para João Mendes de Almeida Júnior,

a esquissa ou inquérito e o processo secreto desenvolveram, pois, o uso da tortura, em consequência dos preconceitos que levaram a jurisprudência a formular, como regra essencial, a necessidade da confissão do acusado. O juiz, habituado a fundar toda a instrução nas contínuas perguntas ao réu, buscava todos os meios de extorquir esta confissão, ostentando uma habilidade sem escrúpulo, quer para a sugestão, quer para as ciladas, quer para o cansaço do interrogado; e, se ainda assim nada conseguisse, recorria às ameaças e depois aos tormentos. (1959, p. 138. v. I).

As sessões eram restritas ao julgador, ao escrivão e ao algoz, curiosamente chamado de ministro. Em momento posterior, face as chagas das expiações, acrescentou-se um médico, ora para averiguar o estado de óbito, ora para aquilatar a resistência orgânica para a retomada dos suplícios. Conforme a ponderação de Nilo Batista:

A importância do estudo da inquisição não se prende apenas ao extenso campo de
sua herança propriamente jurídico-penal, da influência direta que exerceu sobre a
forma e o fundo dos sistemas penais da Europa católica, influência esta que o
empreendimento colonizador transferiria para a América Latina. A inquisição nos
revela com nitidez os laços íntimos que se estabelecem entre um projeto político e o
sistema penal que lhe dá sustentação, e de que forma o segundo se adapta

${ }^{2}$ Para fundamentar sua conclusão, o historiador se utiliza da desproporção entre as condenações e as execuções à
pena de morte: "Na prática, todavia, os dados disponíveis parecem aconselhar uma opinião bem diferente da
mais usual quanto ao rigorismo do sistema penal. Na verdade, a pena de morte natural era, em termos
estatísticos, muito pouco aplicada em Portugal. (...). Comecemos por uma fonte - uma relação de presos da
cadeia de Lisboa, entre 1694 e 1696 , a que nos referimos mais detidamente nos parágrafos seguintes - que nos
faculta dados relativos às medidas penais aplicadas a cerca de trezentos criminosos (em geral, grandes
criminosos). Trata-se de uma lista dos 454 presos que se encontravam na cadeia da cidade de Lisboa, presentes
ao Regedor das Justiças, aquando das visitas que regimentalmente devia fazer à cadeia da corte. A lista terá sido
feita em 1694 , conforme se lê no rosto de ambos os tomos; mas tem acrescentos de outra mão, reportados a datas
posteriores, até 1696 . Em relação a cada réu, registra-se, em geral, o nome, o crime de que vinha acusado, o
lugar do crime, o tempo de prisão já cumprido, o estado da causa, o seu destino final e o nome do escrivão do
processo. Há casos em que algum destes dados falta. Com indicação do crime e da decisão final há 294 casos.
(...). A pena capital apenas foi usada em três casos. [...]. O caráter dos dados e a dimensão da amostra não
permitem, no entanto, detalhar mais a análise. A fonte tratada é, decerto, de uma fonte situada num momento
preciso do tempo, embora com um número significativo de casos. Mas outros testemunhos apontam no mesmo
sentido de uma aplicação efetiva rara da pena de morte. (2012, p. 137-139). CONPEDI LAW REVIEW | EVENTO VIRTUAL | v. 6 | n. 1 | p. 196 - 215 | JAN - DEZ | 2020 
plasticamente aos movimentos do primeiro, dissimulando freqüentemente (sic) no discurso judiciário condenatório a manobra política agressiva. Mas a inquisição nos revela também, pela primeira vez na história, como o sistema penal pode adquirir uma certa autonomia que o desvincule do projeto político que o criou, e como essa poderosa criatura, a serviço de correntes específicas, pode usar conjunturalmente suas armas prestigiadas e ferozes. A inquisição nos permite compreender que o dogmatismo legal, com sua aversão ao pluralismo jurídico, é condição necessária para uma criminalização do diferente, criminalização esta que sinaliza a coercitividade do consenso e o reforça através da manipulação dos sentimentos ativados pelo episódio judicial. Esses mecanismos, que ligam o uso do delito de heresia ao projeto político do papado, sobreviveram à descriminalização histórica da heresia, e ainda podem ser entrevistos em plena vitalidade no século que ora se encerra, com facilidade em conjunturas mais claramente politizadas (judeus perante a ordem nazista, socialistas perante os tribunais militares do Cone Sul etc.), porém sem muito esforço mesmo quando as variáveis políticas estejam encobertas (a "guerra santa" contra as drogas e o traficante-herege que pretende apossar-se da alma de nossas crianças). (2002, p. 238).

No sistema inquisitivo, diferentemente do acusatório, as funções de julgar, acusar e defender são concentradas em uma única autoridade. Não se vislumbra o contraditório e a ampla defesa como instâncias autônomas. O réu torna-se refém de um mero juízo de valor e, por excelência, parcial em sua forma e conveniente em sua essência. A rigor, a acusação esmaga a defesa. A relativização da presunção de inocência, um de seus atributos mais destacados, põe em evidência a prisão cautelar, sem formação de culpa.

No período colonial, inexistentes cursos jurídicos, ao lado do protagonismo de vários escravos na defesa de suas liberdades, as pessoas tinham que solicitar autorização da Corte para a advocacia. Na prática, em muitas oportunidades, a prevalência da máxima do processo penal medieval, segundo a qual o acusado, se inocente, não precisa de advogado; se culpado, não merece. De acordo com o raciocínio de Carlos Guilherme Mota e Adriana Lopez:

\begin{abstract}
A violência da justiça manifestava-se nas prisões arbitrárias, nos castigos exemplares que eram ministrados aos criminosos e na aplicação da pena de morte. Os rigores da lei afetavam especialmente a população mais pobre da colônia e aqueles que não eram proprietários. Os transgressores esperavam suas sentenças durante anos a fio, frequentemente porque não podiam pagar um escrivão. A população de cor - negros forros e mestiços - era castigada com maior severidade. Nas regiões em que a presença da Coroa era mais distante, os grandes proprietários de terras exerciam considerável autoridade administrativa e judicial. No sertão, os potentados impunham seus interesses à população livre, do alto de seus postos de coronel e capitão-mor da milícia. (2008, p. 266).
\end{abstract}

Em 1822, com o processo de independência, fundou-se o Estado imperial. A Constituição, outorgada em 25 de março de 1824, inspirada no constitucionalismo inglês, teve um significado sob o ponto de vista institucional. Em tese, o liberalismo político concebeu todos os homens como cidadãos livres e iguais. Apesar disso, a instituição da escravidão 
permaneceu inalterada, garantida que era pelo direito de propriedade reconhecido na nova Constituição.

A contradição da nova ordem era inequívoca, pois "o pensamento das Luzes considerando inadmissível a escravidão, contestava, na realidade, todo o antigo regime." (PRADO, 2013, p. 167). No tocante ao século XIX, Manuela Carneiro da Cunha aponta a sua peculiaridade para a compreensão da história brasileira e seu contexto no cenário internacional:

\begin{abstract}
O século XIX é um século heterogêneo, o único que conheceu três regimes políticos: embora dois terços do período se passem no Império, ele começa ainda na Colônia e termina na República Velha. Inicia-se em pleno tráfico negreiro e termina com o início das grandes vagas de imigrantes livres. É, como se sabe, um período de tensão entre oligarquias locais e surtos de centralização do poder. É também um século em que o Brasil, à sua maneira, se moderniza: à sua maneira, porque o poder e os privilégios pouco mudam. (1992, p. 133).
\end{abstract}

A proposta liberal, sob o rótulo da igualdade, teve como primeiro embate o dilema entre a cidadania e a escravidão. Os escravos estavam alijados dos direitos insertos nas normas constitucionais, pois lhes incumbiam apenas o cumprimento dos deveres; a eles eram reservados apenas os ônus. Por outro lado, apesar da previsão de direitos individuais, em uma sociedade constituída sob o regime da hierarquia, do mandonismo e do latifúndio, em que "a massa da população livre dependia dos grandes proprietários rurais, onde só um pequeno grupo tinha instrução e onde existia uma tradição autoritária” (FAUSTO, 2012, p. 128), a aplicação era muito relativa, quando não constituía uma quimera.

Uma das ferramentas utilizadas para o progresso do establishment foi a inauguração de faculdades de direito. A estratégia, em um primeiro momento, foi uma no norte e a outra no sul. Em 11 de agosto de 1827 foram criados os cursos de ciências jurídicas e sociais no Convento de São Francisco, em São Paulo (atual Faculdade de Direito da Universidade de São Paulo) e outro no Mosteiro de São Bento, em Olinda (antiga Faculdade de Direito de Olinda), transferida, desde 1854, para o Recife. A finalidade primordial foi fomentar uma identidade própria e construir uma intelligentsia consentânea com os escopos régios. A prosperidade econômica destas duas cidades influenciou decisivamente na construção de uma elite política nacional.

Um número considerável de egressos destas instituições exerceram cargos de prestígio na administração estatal. O ingresso no ensino superior era um privilégio para poucos abastados, pois "como qualquer dessas ocupações demandava extenso período de estudos 
especializados e, por conseguinte, vultosas despesas, apenas os filhos de famílias ricas poderiam aspirar as carreiras nobres." (PANG; SECKINGER, 1972, p. 219).

Outrora, a maioria dos bacharéis em direito estudaram na Universidade de Coimbra. Iniciou-se, por conseguinte, um processo de formação de intelectuais, independente das escolas portuguesa e francesa. Por sua vez, o transplante de regras, institutos e ideias europeias comprometeu parcialmente o sucesso do projeto. Para José Murilo de Carvalho:

O Brasil dispunha, ao tornar-se independente, de uma elite ideologicamente homogênea devido a sua formação jurídica em Portugal, a seu treinamento no funcionalismo público e ao isolamento ideológico em relação a doutrinas revolucionárias. Essa elite se reproduziu em condições muito semelhantes após a Independência, ao concentrar a formação de seus futuros membros em duas escolas de direito, ao fazê-los passar pela magistratura, ao circulá-los por vários cargos políticos e por várias províncias. (2011, p. 39).

Em caráter paralelo ao constitucionalismo e seguindo a tendência da Europa central pela codificação, o Império modificou a legislação infraconstitucional. Em primeiro lugar, a justiça penal, cuja disciplina anterior estava estabelecida no Livro V das Ordenações Filipinas: i) Código Criminal: lei de 16 de dezembro de 1830; ii) Código de Processo Criminal: lei de 29 de novembro de 1832; e iii) normas extravagantes, como as regras instituídas pelo Ministério da Justiça e os pareceres do Instituto dos Advogados do Brasil IAB.

No bojo desta transformação, o Tribunal do Júri simbolizou a inserção do povo na organização e funcionamento da justiça. Ademais, a disciplina do habeas corpus, instrumento de defesa da liberdade previsto no Código Criminal de 1830 e no Código de Processo Criminal de 1832, representou, inegavelmente, uma mudança de paradigma, seja em virtude de uma herança haurida sob o signo do despotismo, seja em face da sua previsão ante uma monarquia constitucional.

Em 1843, após a denominada década liberal (1831-1841) ${ }^{3}$ e o reinício da centralização e expansão da atividade policial ${ }^{4}$, foi inaugurado o Instituto dos Advogados Brasileiros -

\footnotetext{
3 "La primera gran reforma de la década liberal fue también la primera modificación importante del sistema judicial. La creación em 1827 del puesto de juiz de paz (juez de paz) señaló el comienzo del período de reforma y el ascenso inminente de los liberales. (...). Los tradicionalistas y conservadores vieron en el magistrado local uma erosión de mal agüero de la autoridad central y uma amenaza al control social en el vasto imperio". (FLORY, 1986, p. 81).

${ }^{4}$ A Lei 261 , de 3 de dezembro de 1841, foi responsável pela reforma processual penal. Foi regulamentada pelo Decreto 120, de 31 de janeiro de 1842. "O juiz de paz eleito, poderoso durante a Regência, perdera boa parte de suas funções em favor dos delegados de polícia." (CARVALHO, 2005, p. 169). 
IAB, também conhecido como "Casa de Montezuma", marco na difusão de teses e debates sobre o direito à liberdade. As disputas entre libertos, escravos e proprietários provocaram uma celeuma nos tribunais, com destaque para as incoerências nas decisões. Os jurisconsultos do IAB tiveram como desígnio uniformizar o entendimento sobre a dinâmica de aplicação e interpretação de normas sobre o instituto da escravidão, entre outros temas, desde as Ordenações até a legislação mais moderna.

Ressalte-se, nesta conjuntura, as controvérsias entre Caetano Alberto Soares e Augusto Teixeira de Freitas a respeito das ações cíveis de liberdade. A principal delas consistiu na condição de livre ou cativo dos filhos concebidos por uma escrava à época em que foi deixada forra com a obrigação de prestar serviços. De acordo com a concepção de Alberto Soares, eles seriam livres, mesmo antes do implemento da condição. A fim de alicerçar seu parecer, ele defendeu o recurso à "Lei da Boa Razão", de 18 de agosto de 1769, a qual, elaborada pela Coroa portuguesa, teve como objetivo primordial enumerar em quais hipóteses o direito romano poderia ser invocado quando existissem lacunas nas Ordenações Filipinas.

Em reforço da tese, utilizou-se de um argumento oriundo do direito civil de Roma: o bem acessório segue o destino do objeto principal, vale dizer, o filho de escrava permaneceria escravo, e não livre, como previsto na Lei do Ventre Livre. "O presidente do Instituto, nesta ocasião, era justamente o maior romanista do Brasil, e o responsável pela organização das leis civis que regulariam, entre outros temas, o direito de propriedade: Teixeira de Freitas." (ALMEIDA, 2007, p. 88). O entendimento do IAB foi em prol da liberdade. O malogro de sua teoria não restou incólume, uma vez que provavelmente suscitou a renúncia ao seu exíguo mandato: três meses. Entretanto, sobre as qualidades morais e conveniências dos juristas, pondera Eduardo Spiller Pena:

Como "soldados" exemplares da emancipação, os voluntários-jurisconsultos, em sua arena jurídica, tinham o dever providencial de guiar a nação rumo à civilização e ao progresso, evitando, contudo, nessa transformação, qualquer desrespeito aos direitos dos cidadãos-proprietários e, consequentemente, qualquer perigo ou desordem ao Estado imperial. (...). Às vezes, os próprios jurisconsultos que conceberam, em seus discursos ou "memórias", as medidas para o "melhoramento da sorte dos escravos", negaram-nas terminantemente em ambientes de maior repercussão pública. (2001, p. 361-362).

\footnotetext{
5 O nome é uma homenagem a Francisco Brandão Gomes, fundador do IAB, o qual passou a se chamar Francisco Gê Acayaba de Montezuma, visconde de Jequitinhonha.

${ }^{6}$ Conforme explica Eduardo Spiller Pena: "Em casos omissos, poder-se-ia recorrer, conforme ditavam as ordenações portuguesas, ao direito romano, desde que os dispositivos escolhidos fossem fundados na boa razão. Para os juristas que elaboravam o discurso emancipacionista, o argumento da boa razão foi frequentemente veiculado como um preceito jurídico-moral a favor da liberdade. No caso de Caetano Soares, a apropriação do direito romano foi realizada de forma ambígua, pois, a partir do preceito, escolheu-se um dispositivo regulador de uma relação escravista, a fim de sustentar, por ele, uma argumentação favorável à liberdade”. (2001, p. 89).
} 
A história oficial é pródiga em deturpações e condecorações de heróis e mártires. Enquanto uns recebem efusivos aplausos, Machado de Assis, José do Patrocínio e André Rebouças, genuínos abolicionistas, possuem reconhecimentos moderados, quando não são propositalmente olvidados pela literatura. Outro símbolo da resistência foi Luiz Gonzaga Pinto da Gama, respeitado tanto entre os negros quanto entre os eméritos da Faculdade de Direito de São Paulo. "Vivendo modestamente de seu trabalho como advogado, Luiz Gama empenhava todos os recursos na defesa dos mais necessitados. Com o dinheiro que ganhava ele ia alforriando outros escravos." (FRAGA, 2005, p. 50). A historiografia ratifica que foi um dos raríssimos casos em que um negro se tornou intelectual no Brasil. Para Sidney Chalhoub,

Luiz Gama é personagem de tirar o fôlego. Filho de fidalgo português e de africana
livre, passou a infância com a mãe na Salvador dos anos 1830 , década de
insurreições escravas e pânico dos brancos. A africana teve de deixar a Bahia,
fugindo da repressão senhorial, e o pai fidalgo acabou vendendo o filho ilegalmente
como cativo para cobrir dívidas de jogo. [...]. O menino ficou na cidade de São
Paulo, angariou a simpatia de protetores poderosos, alfabetizou-se, provou que tinha
direito à liberdade, instruiu-se ainda mais. No período em que a instituição da
escravidão passava de "mal necessário" a "problema que exigia solução", Luiz
Gama escreveu livro de versos satíricos, tornou-se funcionário público, aderiu ao
movimento republicano paulista, editou jornais, aprendeu a advogar na prática do
foro e, com a ajuda de uma loja maçônica, colocou todo o conhecimento jurídico
que obteve a serviço da causa da liberdade dos escravos. Adotou "a causa dos
desgraçados", sem pretender lucros, sem temer ameaças. Virou legenda. Uma vida
destemida, épica, quase inverossímil naquele Brasil escravocrata, em que a tortura
de trabalhadores era ato da rotina de produção. (1999, p. 16).

O IAB pode ser apontado como o antecedente mais remoto da Ordem dos Advogados do Brasil - OAB, criada apenas em 1930. Um dos herdeiros mais proeminentes do caudilhismo na América Latina, líder da Revolução de 30, Getúlio Vargas assumiu o poder e o controle do Judiciário em 3 de novembro e, quinze dias após, criou a $\mathrm{OAB}$ a fim de controlar os advogados. O ato decorreu do Decreto 19.408 , de 18 de novembro de $1930^{7}$. As origens da assistência jurídica estão na Lei 261/1841, que previa o pagamento de metade das custas judiciais pela Câmara Municipal, no caso de processo contra réus pobres. Surpreendentemente, trata-se do mesmo diploma responsável pela centralização do poder. $\mathrm{O}$ Regulamento 120/1842 esmiuçou a execução da parte policial e criminal ${ }^{8}$.

\footnotetext{
${ }^{7}$ Art. 17. Fica criada a Ordem dos Advogados Brasileiros, orgão de disciplina e seleção da classe dos advogados, que se regerá pêlos estatutos que forem votados pelo Instituto da Ordem dos Advogados Brasileiros, com a colaboração dos Institutos dos Estados, e aprovados pelo Governo.

${ }^{8}$ Art. 154. Quando na occasião da soltura o preso se recusar ao pagamento da carceragem, o Carcereiro poderá demora-lo por tres dias, se fôr livre e tiver meios para pagar, mas neste caso entender-se-ha que renunciou ao CONPEDI LAW REVIEW | EVENTO VIRTUAL | v. 6 | n. 1 | p. 196 - 215 | JAN - DEZ | 2020 
No início do período republicano, no Estado do Rio de Janeiro, em 8 de fevereiro de 1897, por intermédio do Decreto 2.457, instituiu-se a Assistência Judiciária no Distrito Federal. No plano constitucional, a Constituição Federal de $1934^{9}$, em seu art. 113, 32, contemplou o direito de acesso gratuito à Justiça, nos seguintes termos: “A União e os Estados concederão aos necessitados assistência judiciária, criando, para esse efeito, órgãos especiais e assegurando a isenção de emolumentos, custas, taxas e selos." O Código de Processo Penal de 1941, em seus artigos 32 e 263, adotou regras segundo as quais, em não tendo o acusado ou o autor da ação penal privada condições de contratar advogado, o juiz lhe nomearia um. Embora a Constituição de 1946 tenha previsto semelhante norma, ambas foram efêmeras e tiveram inexpressiva efetividade.

No Estado do Rio de Janeiro, a Lei Estadual n².188, de 21 de julho de 1954, criou, no âmbito da Procuradoria Geral de Justiça, os seis primeiros cargos de "defensor público". A Constituição de 1988 foi a pioneira em prescrever a Defensoria Pública como instituição permanente, essencial à função jurisdicional do Estado, incumbindo-lhe, como expressão e instrumento do regime democrático, fundamentalmente, a orientação jurídica, a promoção dos direitos humanos e a defesa, em todos os graus, judicial e extrajudicial, dos direitos individuais e coletivos, de forma integral e gratuita, aos necessitados. ${ }^{10}$

\section{Constituição, processo e devido processo legal}

$\mathrm{O}$ direito de acesso à justiça deve ser compreendido como o direito a uma ordem jurídica socialmente justa. Essa premissa é fundamental para entender a demanda das classes populares e o contexto da Defensoria Pública como órgão de uma democracia liberal e, portanto, capitalista. Não há capitalismo sem pobreza. Apesar desse vínculo quase umbilical

mesmo pagamento. Se o preso fôr escravo, não será entregue, emquanto esse pagamento não se effectuar. (...). Art. 157. Aos presos pobres se fornecerá almoço e jantar parcos, porém saudaveis.

9 "É somente a partir da década de 1980 que se iniciam algumas transformações para assegurar a efetividade do direito ao acesso à justiça no Brasil, principalmente no que se refere à sua democratização e utilização como forma de garantir e concretizar os direitos individuais, econômicos, sociais e coletivos". (BEDIN; SPENGLER, 2013, p. 140-143).

${ }^{10}$ Em que pese o artigo $134, \S 2^{\circ}$, da $\mathrm{CF} / 88$ assegurar autonomia funcional e administrativa e a iniciativa de sua proposta orçamentária dentro dos limites estabelecidos na lei de diretrizes orçamentárias, a efetividade do preceito restou totalmente comprometida com o veto integral da ex-presidenta da República, Sra. Dilma Rousseff, ao PLC 114/11, o qual atribuía às Defensorias Públicas dos Estados os direitos e deveres previstos na Lei de Responsabilidade Fiscal (LC 101/2000). O texto previa a destinação do percentual mínimo de $2 \%$ do orçamento líquido dos Estados às Defensorias, como estabelecido para o Ministério Público. Além disso, no sentido da universalização do acesso à justiça no Brasil, o Congresso Nacional promulgou a EC 80/2014, a qual estabelece um prazo de oito anos, ou seja, até 2022, para que todas as comarcas do país tenham defensores públicos. Trata-se de perspectiva longínqua, principalmente após a promulgação da EC 95/2016, a qual permite o reajuste do orçamento somente de acordo com a inflação do ano anterior. 
da Defensoria Pública, é perfeitamente possível a afirmação no sentido de que a sua gênese foi simultaneamente a sua emancipação.

Se, em um primeiro momento, ela funcionou mais como uma concessão do que como uma conquista da cidadania, a história demonstrou a sua imprescindibilidade para a consolidação da democracia social, econômica e política. A sua previsão constitucional foi contemplada por todos, mas festejada pelos mais humildes. Conforme a lição de Victor-Marie Hugo: "E se a balança deve pender, que seja para o lado do povo. Ele sofre há mais tempo." (2014, p. 80). Sob esta ótica, o estabelecimento de uma instituição cuja função precípua é a defesa dos necessitados deve ser interpretada como um avanço significativo na trajetória do Estado.

$\mathrm{O}$ acesso à justiça pode e deve ser concebido como "o requisito fundamental - o mais básico dos direitos humanos - de um sistema jurídico moderno e igualitário que pretenda garantir e não apenas proclamar o direito de todos." (CAPPELLETTI; GARTH, 1988, p. 12). O eixo axiológico do processo penal justo possui como pontos de partida e de chegada o ser humano, sobretudo quando acusados, pois “a civilização de um país é medida pela forma com que são tratadas as pessoas mais vulneráveis.” (PERLINGIERI, 2010, p. 787). Este entendimento é consentâneo com a jurisprudência da Corte Interamericana de Direitos Humanos. A título de ilustração, o voto de Antônio Augusto Cançado Trindade no caso "Instituto de Reeducação do Menor vs. Paraguai”, paradigmático na proteção dos direitos de jovens privados de liberdade:

Além das ofensas aos dispositivos da Convenção Americana de Direitos
Humanos, várias Regras de Beijing (Regras Mínimas das Nações Unidas para a
Administração da Justiça de Menores) foram desrespeitadas. (...). 26. Tudo isso
revela o relevante papel reservado ao devido processo legal no Estado democrático
de Direito. Por conseguinte, jamais se justificaria uma interpretação restritiva do
mesmo. A Corte Interamericana sempre concedeu um amplo alcance ao artigo 8 da
Convenção Americana. Assim o fez, com especial ênfase, v.g., no Caso Baena
Ricardo e Outros Vs. Panamá (Sentença de 2.02 .2001 , pars. 124-127), ponderando
que, em última instância, a justiça se realiza através do devido processo legal, como
"verdadeiro valor juridicamente protegido" (par. 129). A meu juízo, a ampla
dimensão do devido processo legal se depreende de sua íntima relação com o
direito de acesso (lato sensu) à justiça. (...). A origem - pouco conhecida - desta
garantia judicial é latino-americana: de sua consagração originalmente na
Declaração Americana dos Direitos e Deveres do Homem (de abril de 1948), foi
transplantada à Declaração Universal dos Direitos Humanos (de dezembro de
1948), e dali às Convenções Europeia e Americana sobre Direitos Humanos
(artigos 13 e 25, respectivamente), bem como ao Pacto sobre Direitos Civis e
Políticos das Nações Unidas (artigo 2(3)). (...). 28 . A Corte Interamericana
reconheceu a importância do direito de acesso à justiça; tanto é assim que, desde sua
Sentença de 3.11 .1997 (par. 82), no Caso Castillo Páez Vs. Peru, até a presente data,
afirmou reiteradas vezes que o direito de toda pessoa de acesso a um recurso 
simples, rápido e efetivo perante juízes ou tribunais competentes que amparem seus direitos fundamentais (artigo 25 da Convenção) "constitui um dos pilares básicos, não somente da Convenção Americana, mas do próprio Estado de Direito em uma sociedade democrática no sentido da Convenção". (CORTE INTERAMERICANA DE DIREITOS HUMANOS, 2004, destaque nosso).

O Estado Democrático de Direito se legitima e se reafirma somente por intermédio da busca incessante pela equação entre igualdade jurídica e desigualdade econômica, entre a presunção de inocência e a efetividade da justiça criminal. A ampla defesa assume maior dimensão no processo penal. Como expressão máxima de cultura e civilização, o processo se materializa principalmente com a consecução da cláusula do devido processo legal e seus consectários, os princípios do contraditório e da ampla defesa. Com efeito,

posta a acusação, deve-se duvidar dela. Não por razões associadas às peculiaridades
do caso, mas como método de exploração na formação do convencimento judicial. A
estrutura dialética do processo - já assentada definitivamente - deve iniciar-se não
pela acusação, mas pela sua negação. O que deve ser potencializado é a contradição
e não a afirmação. Sempre será possível justificar a absolvição de um efetivamente
culpado; já a condenação de um concretamente inocente não. O custo social é
impagável. (OLIVEIRA, 2009, p. 74).

$\mathrm{O}$ due process of law, conforme a sua origem inglesa, representa concomitantemente uma garantia do processo, das partes e da própria jurisdição. Uma justiça substantiva, mormente em um cenário de complexas desigualdades econômicas, não se coaduna com o cerceamento do direito de defesa, a preterição do contraditório e a duração irrazoável do processo penal. Conforme leciona Carlos Roberto Siqueira Castro:

A não ser assim, a beleza luminosa da garantia do devido processo legal, moldada
nas mais caras tradições do constitucionalismo, reluzirá apenas para uma ínfima
maioria, restando opaca para o grande e marginalizado contingente da população
que frequenta as estatísticas criminais, por sua vez, o retrato fiel das sociedades que
combatem a desigualdade com a repressão. [...] Tal é necessário para que a clientela
de nossas superpopulosas prisões comece o quanto antes a modificar o costumeiro e
desumano perfil: negros, indigentes, desempregados, egressos das favelas
explosivas, enfim, a multidão de miseráveis e de vítimas de um capitalismo
predatório que arrasa o terceiro mundo e que espera paciente (não se sabe como!) o
inadiável resgate social por parte dos governos e da sociedade civil. (2010, p. 287-
288).

Trata-se de uma garantia que funciona em "nosso ordenamento jurídico como guardachuva, sob a qual se abrigam direitos, garantias, princípios, regras, valores, deveres e proibições, catalogadas e implícitas" (GIACOMOLLI, 2016, p. 99), irradiando seus efeitos tanto na esfera nacional quanto internacional. Não há um modelo constitucional de processo penal sem a observância irrestrita da cláusula do devido processo legal. É a espinha dorsal da jurisdição penal, pois uma lacuna, parcial ou total, mutila o Estado e deslegitima a condenação. 


\title{
4. O sistema prisional no Brasil.
}

Há quase cem anos, Oliveira Vianna" consignou: "em todos esses sicários, a mestiçagem é visível, claríssima.” (2002, p. 1065. v. I). Em 2017, conforme estudo do Departamento Penitenciário Nacional, do Ministério da Justiça, o total de pessoas encarceradas no Brasil chegou a 726.712. O Brasil é o terceiro país com maior número de pessoas presas, atrás apenas de Estados Unidos e China. A política criminal no Brasil, principalmente no século XXI, é a do encarceramento em grande escala.

Em 2000, por exemplo, o contingente carcerário era de 232.755 pessoas. Em dezembro de 2014, era de 622.202. Cerca de 40\% são presos provisórios, ou seja, ainda não possuem condenação judicial. Mais da metade dessa população é de jovens de 18 a 29 anos e 64\% são negros. No Estado do Ceará, primeiro no ranking, o índice de encarcerados sem a formação de culpa é de $66 \%$.

Estes dados são um reflexo, em grande medida, da ausência da Defensoria Pública nas comarcas do interior do País. Em relação à esfera estadual, conforme a última catalogação, de 2015, “a média nacional de atendimento por comarcas é de, aproximadamente, 40\%". (BRASIL, 2015, p. 59). “Quarenta e dois por cento daqueles na prisão no Brasil não foram condenados, 80 por cento dos prisioneiros no Brasil são incapazes de pagar um advogado privado". (FINGERMANN, 2013, p. 24). Nos rincões do Brasil, é praxe a jurisdição penal se desenvolver por meio de advogados dativos ou nomeados pelos alcaides em cumprimento de protocolos político-partidários. Neste particular, Luigi Ferrajoli defende:

\begin{abstract}
A paridade das partes requer por sua vez duas específicas condições orgânicas, relativas à sua configuração e colocação institucional. A primeira condição concerne à acusação. Se é indispensável que o juiz não tenha funções acusatórias, é igualmente essencial que a acusação pública não tenha funções judiciais. [...]. A segunda condição concerne à defesa, que deve ser dotada da mesma dignidade e dos mesmos poderes de investigação do Ministério Público. Uma igual equiparação só é possível se ao lado do defensor de confiança é instituído um defensor público, isto é, um magistrado destinado a funcionar como Ministério Público de Defesa, antagonista e paralelo ao Ministério Público de Acusação. A instituição dessa "magistratura" ou "tribuna da defesa" como uma ordem separada tanto da judicante como da postulação foi proposta por Filangieri, por Bentham, e depois por Carrara e por Lucchini, sob o pressuposto de que a tutela dos inocentes e a refutação às provas de culpabilidade integram funções do interesse não menos público de punição dos
\end{abstract}

\footnotetext{
${ }^{11}$ Francisco José de Oliveira Vianna (1883-1951) foi advogado, professor de direito criminal na Faculdade do Estado do Rio de Janeiro, membro da Academia Brasileira de Letras, membro do Instituto Histórico e Geográfico Brasileiro e consultor jurídico do Ministério do Trabalho, período no qual influenciou decisivamente na elaboração da legislação sindical e trabalhista do governo de Getúlio Vargas. Sua primeira obra, Populações meridionais do Brasil, foi publicada em 1920. 
culpados e da colheita de provas a cargo da acusação. É claro que apenas desse modo seria eliminada a disparidade institucional que de fato existe entre acusação e defesa, e que confere ao processo, ainda mais que o segredo e a escritura, caráter inquisitório. Obviamente, tal magistrado não só não deveria substituir o defensor de confiança, como deveria sustentá-lo como órgão complementar, subsidiário e subordinado às estratégias defensivas previamente selecionadas por este. Dotado dos mesmos poderes da acusação pública sobre a polícia judiciária e habilitado à coleta das contraprovas, ele garantiria todavia uma efetiva paridade entre as funções públicas da prova e aquela não menos pública da refutação. E asseguraria, além disso, contrariamente à hodierna função do "defensor público", uma efetiva igualdade dos cidadãos no exercício do direito de defesa. É fácil compreender que semelhante figura encontrará sempre a oposição corporativa da categoria dos advogados. Mas sem ela resulta comprometida a paridade de partes, que forma um dos pressupostos essenciais do contraditório e do direito de defesa. ${ }^{12}$ (2010, p. 537538, destaque nosso).

Os crimes relacionados ao tráfico de drogas são os que mais levam pessoas às prisões, com $28 \%$ da população carcerária total. Somados, roubos e furtos chegam a 37\%. Homicídios representam $11 \%$ dos crimes que causaram a prisão. Quanto à escolaridade, $75 \%$ da população prisional brasileira não chegaram ao ensino médio. Menos de $1 \%$ dos presos tem graduação. ${ }^{13}$ (MINISTÉRIO DA JUSTIÇA, 2017).

Ressalte-se que este fenômeno se desenvolveu logo após a promulgação da Constituição Federal de 1988, a qual foi responsável pela previsão de um amplo catálogo de princípios, garantias e direitos fundamentais, como a expressa vedação da tortura e de tratamento desumano ou degradante, o respeito à integridade física e moral dos presos e a presunção de inocência (art. 5, III, XLIX e LVII, respectivamente). O Supremo Tribunal Federal, em 2015, na Ação de Descumprimento de Preceito Fundamental 347 MC/DF, entendeu que

\begin{abstract}
vigora no sistema penitenciário brasileiro um "estado de coisas inconstitucional", ou seja, uma violação generalizada de direitos. Esta nomenclatura foi elaborada pela Corte Constitucional da Colômbia, em 1997. O Plenário anotou que no sistema prisional brasileiro ocorreria violação generalizada de direitos fundamentais dos presos no tocante à dignidade, higidez física e integridade psíquica. As penas privativas de liberdade aplicadas nos presídios converter-se-iam em penas cruéis e desumanas. (BRASIL, 2015).
\end{abstract}

A decisão proferida no Habeas Corpus 126.292/SP traduziu, irrefutavelmente, o maior giro hermenêutico em matéria de restrição de direitos fundamentais. O acórdão teve como

\footnotetext{
12 “A Defensoria Pública (DP) - na qualidade de órgão interveniente -, tem missão distinta do Ministério Público (MP), pois enquanto este último (MP) tem seu papel constitucional conectado à objetiva tutela da ordem jurídica enquanto Custos legis et juris (guardião da lei e da ordem jurídica), a Defensoria Pública age em favor do progresso dos necessitados (lato sensu), como guardiã dos vulneráveis e dos excluídos (Custos vulnerabilis et plebis), assim como amiga das comunidades carentes (Amicus communitas)."(SANTIAGO; MAIA, 2019, p. 204).

${ }^{13} 6.638$ pessoas faleceram nos cárceres entre 2014 e 2017, uma média de mais de quatro mortes por dia. CONPEDI LAW REVIEW | EVENTO VIRTUAL | v. 6 | n. 1 | p. 196 - 215 | JAN - DEZ | 2020 
ponto central a tentativa de equação entre o postulado da presunção de inocência e a efetividade da função jurisdicional penal. De acordo com a decisão do Plenário do Supremo Tribunal Federal, "tal equilíbrio deveria atender a valores caros não apenas aos acusados, mas também à sociedade, diante da realidade do intrincado e complexo sistema de justiça criminal brasileiro." (BRASIL, 2017). Houve, nitidamente, um compromisso da Suprema Corte com a condenação e com a prisão, como se a absolvição e a defesa em liberdade não representassem justiça.

A tese vencedora asseverou que o artigo 5, LVII, da Constituição da República "não esbarra na necessidade do trânsito em julgado da decisão condenatória, mas tangencia o imperativo da comprovação da culpabilidade na forma da lei e o duplo grau de jurisdição." (SUXBERGER; AMARAL, 2017, p. 193). Todavia, a norma não concede margem para a teratológica interpretação: ninguém será considerado culpado até o trânsito em julgado de sentença penal condenatória.

Há uma desproporção entre o número de negros ${ }^{14}$ na população brasileira $(54,9 \%)$ e o de negros presos (64\%). De acordo com o recenseamento demográfico de 2017, entre 2012 e 2016, a participação percentual dos brancos na população do país caiu de 46,6\% para 44,2\%, enquanto a participação dos pardos aumentou de $45,3 \%$ para $46,7 \%$ e a dos pretos, de $7,4 \%$ para $8,2 \%$. Desemprego entre pessoas pretas e pardas chega a $14,6 \%$ e cai para $9,9 \%$ para as brancas. O Brasil tinha 13 milhões de pessoas sem ocupação no terceiro trimestre de 2017. Desse total, 8,3 milhões, ou 63,7\% se declaram pretos ou pardos. Com isso, a taxa de desocupação dessa parcela da população ficou em 14,6\%, valor superior à apresentada entre os trabalhadores brancos $(9,9 \%)$. (INSTITUTO BRASILEIRO DE GEOGRAFIA E ESTATÍSTICA, 2017).

\section{Conclusão}

A conclusão de violação generalizada dos direitos humanos nos cárceres brasileiros por parte do Supremo Tribunal Federal na ADPF 347 corrobora o raciocínio de que o estágio de eficácia do acesso à justiça é incompatível com a democracia. A incongruência é que, exatamente sob a égide da Constituição de 1988, houve uma proliferação de leis penais

\footnotetext{
${ }^{14} \mathrm{O}$ enfoque da pesquisa do Ministério da Justiça inclui no gênero "negros" os pardos e os pretos; todavia, o estudo do Instituto Brasileiro de Geografia e Estatística apresenta o número de pardos e pretos. 
incriminadoras e, consequentemente, uma expansão atípica de presos em comparação com as décadas anteriores.

As desigualdades sociais, a seletividade do sistema penal e a cultura jurídica autoritária podem ser apontadas como as causas principais de um Estado de exceção permanente, cujas vítimas são, em expressiva estatística, negros, pobres e jovens. A reação estatal contra a insegurança pública consiste, basicamente, em orçamento mais robusto para a defesa e para a construção de estabelecimentos prisionais. Entretanto, obviamente, as cifras destinadas não têm repercussão significativa no recuo da delinquência e, em grande medida, não debelam o cerne do problema.

Trata-se, pois, de um problema complexo que se relaciona diretamente com a consolidação da democracia e com a eficácia dos direitos e garantias fundamentais, entre os quais o de acesso à justiça. A resolução reclama uma análise minuciosa e uma ação coesa e multidisciplinar que envolva a universidade e os poderes da República. Sem um engajamento científico e uma política de Estado, os progressos serão muito pífios perante os desafios da criminalidade.

É inadmissível dar respostas singulares para questões plurais. Em uma sociedade construída sob o discurso do ódio e o exercício da repressão, entre cidadãos sobreintegrados e subintegrados caracterizados pela inclusão marginal como devedores e perigosos, a grandeza do Estado consiste fundamentalmente no direito de defesa das pessoas.

\section{Referências.}

ALMEIDA, Eneá de Stutz e. Ecos da Casa de Montezuma: o Instituto dos Advogados Brasileiros e o pensamento jurídico nacional. Florianópolis: Conceito Editorial, 2007.

ALMEIDA JÚNIOR, João Mendes de. O processo criminal brasileiro. 4. ed. Rio de Janeiro; São Paulo: Livraria Freitas Bastos S.A., 1959. v. I.

ANTONIL, André João. Cultura e opulência do Brasil por suas drogas e minas. Brasília: Senado Federal, Conselho Editorial, 2011.

ASSIS, Joaquim Maria Machado de. Quincas Borba. São Paulo:Ática, 1997.

BATISTA, Nilo. Matrizes ibéricas do sistema penal brasileiro - I. 2. ed. Rio de Janeiro: Instituto Carioca de Criminologia; Revan, 2002. 
Os sistemas penais brasileiros. In: ANDRADE, Vera Regina Pereira de (org.). Verso e reverso do controle penal: (des) aprisionando a sociedade da cultura punitiva. Florianópolis: Fundação Boiteux, 2002. p. 147-158.

BEDIN, Gabriel de Lima; SPENGLER, Fabiana Marion. O direito de acesso à justiça e as constituições brasileiras: aspectos históricos. Revista de Direitos Fundamentais e Democracia, Curitiba, v. 14, n. 14, p. 135-146, jul./dez, 2013.

BOXER, Charles R. O império marítimo português: 1415-1825. Lisboa: Edições 70, 2017.

BRASIL. Decreto 2.457, de 8 de fevereiro de 1897. Organisa a Assistencia Judiciaria no Districto Federal. Senado Federal, Districto Federal, 1897. Disponível em: http://www.senado.gov.br. Acesso em: 2 abr. 2019.

BRASIL. Decreto 19.408, de 18 de novembro de 1930. Reorganiza a Corte de Apelação e dá outras providências. Presidência da República, Districto Federal, 1930. Disponível em: http://www.planalto.gov.br. Acesso em: 2 abr. 2019.

BRASIL. Ministério da Justiça. IV Diagnóstico da Defensoria Pública no Brasil. Brasília: Ministério da Justiça, Secretaria de Reforma do Judiciário, 2015.

BRASIL. Regulamento $\mathrm{n}^{\circ} 120$, de 31 de janeiro de 1842 . Regula a execução da parte policial e criminal da Lei $n^{\circ}$ 261, de 3 de dezembro de 1841.Império, Rio de Janeiro, 1842.Disponível em: http://www.planalto.gov.br. Acesso em: 2 abr. 2019.

BRASIL. Supremo Tribunal Federal. ADC 43/DF. Rel. Min. Marco Aurélio, julgamento em 7.11.2019.

BRASIL. Supremo Tribunal Federal. ADPF 347 MC/DF. Rel. Min. Marco Aurélio. Diário de Justiça, Brasília, 11 set. 2015.

CAPPELlETTI, Mauro; GARTH, Bryant. Acesso à justiça. Tradução de Ellen Gracie Northfleet. Porto Alegre: Sérgio Antônio Fabris, 1988.

CARVAlHO, José Murilo de. A construção da ordem: a elite política imperial. Teatro de sombras: a política imperial. 6. ed. Rio de Janeiro: Civilização Brasileira, 2011.

. Pontos e bordados - escritos de história e política, federalismo e centralização no Império brasileiro: história e argumento. Belo Horizonte: Editora da UFMG, 2005, p. 169.

CASTRO, Carlos Roberto Siqueira. O devido processo legal e os princípios da razoabilidade e da proporcionalidade. 5. ed. Rio de Janeiro: Forense, 2010.

CHALHOUB, Sidney. Prefácio. In: AZEVEDO, Elciene. Orfeu de carapinha: a trajetória de Luiz Gama na imperial cidade de São Paulo. Campinas, SP: Editora da Unicamp, 1999. p. 1517. 
CORTE INTERAMERICANA DE DIREITOS HUMANOS - Corte IDH. Caso Instituto de Reeducação do Menor vs Paraguai. Sentença de 2 de Setembro de 2004.

CUNHA, Euclydes da. Os sertões: campanha de Canudos. 39. ed. Rio de Janeiro: Livraria Francisco Alves Editora; Publifolha, 2000.

CUNHA. Manuela Carneiro da. Política indigenista no século XIX. In: (org.). História dos índios no Brasil.2. ed. São Paulo: Companhia das Letras; Secretaria Municipal de Cultura; Fapesp, 1992. p. 133- 154.

FAUSTO, Boris. História do Brasil. 14. ed. São Paulo: Editora da Universidade de São Paulo, 2012.

FERRAJOLI, Luigi. Direito e razão: teoria do garantismo penal. 3. ed. Tradução de Ana Paula Zomer Sica, Fauzi Hassan Chouckr, Juarez Tavares e Luiz Flávio Gomes. São Paulo: EditoraRevista dos Tribunais, 2010.

FINGERMANN, Isadora. The challenges of access to justice and enforcement of the right to counsel in Brazil. Centre for Crime and Justice Studies. CJM, n. 92, June 2013. p. 24-25.

FLORY, Thomas. El juez de paz y el jurado enel Brasil imperial, 1808-1871. Control social y estabilidad política en el nuevo Estado. Tradução de Mariluz Caso. México: Fondo de Cultura Económica, 1986.

FRAGA, Myriam. Luiz Gama. São Paulo: Instituto Callis, 2005.

GORENDER, Jacob. O escravismo colonial. 4. ed. São Paulo: Fundação Perseu Abramo, 2010 .

HESPANHA, António Manuel Botelho. Caleidoscópio do Antigo Regime. Alameda. São Paulo: Alameda, 2012.

HUGO, Victor-Marie. Os miseráveis. Tradução de Regina Célia de Oliveira. São Paulo: Editora Martin Claret, 2014.

IANNI, Octavio. Escravismo e racismo. São Paulo: Editora Hucitec, 1978.

INSTITUTO BRASILEIRO DE GEOGRAFIA E ESTATÍSTICA. População chega a 205,5 milhões, com menos brancos e mais pardos e pretos. Disponível em: http://www. agenciadenoticias.ibge.gov.br.Acesso em: 27 nov. 2017.

LACERDA, Marina Basso. O novo conservadorismo brasileiro. Porto Alegre: Zouk, 2019.

MALHEIRO, Agostinho Marques Perdigão. A escravidão no Brasil: ensaio jurídico, histórico, social. Rio de Janeiro: Vozes, 1976, p. 52. v. I.

MATTOSO, Kátia Mytilineou de Queirós. Ser escravo no Brasil. Tradução de James Amado. São Paulo: Brasiliense, 2003. 
MINISTÉRIO DA JUSTIÇA. Há $\mathbf{7 2 6 . 7 1 2}$ pessoas presas no Brasil. Disponível em:http://www.justica.gov.br/news/ha-726-712-pessoas-presas-no-brasil. Acesso em: 8 dez. 2017.

MOTA, Carlos Guilherme; LOPEZ, Adriana. História do Brasil: uma interpretação. São Paulo: Editora Senac São Paulo, 2008.

OLIVEIRA, Eugênio Pacelli de. O processo penal como dialética da incerteza. Revista de Informação Legislativa, Brasília, a. 46, n. 183, p. 67-75, jul./set. 2009.

PANG, Eul-Soo; SECKINGER, Ron L. The mandarins of imperial Brazil. Comparative studies in society and history. London: Cambridge University Press, v. 14, n. 2, p. 215-244, march 1972.

PENA, Eduardo Spiller.Pajens da casa imperial: jurisconsultos, escravidão e a Lei de 1871. Campinas, SP: Editora da Unicamp, Centro de Pesquisa em História Social da Cultura, 2001.

PIERANGELli, José Henrique. Processo penal: evolução histórica e fontes legislativas. Bauru, SP: Jalovi, 1983.

PRADO, Maria Emilia. Ordem liberal, escravidão e patriarcalismo: as ambiguidades do Império do Brasil. In: ; GUIMARÃES, Lúcia Maria Paschoal (orgs.). O liberalismo no Brasil imperial: origens, conceitos e práticas. 2. ed. Rio de Janeiro: Revan; UERJ, 2013. p. 163-189.

PRADO JÚNIOR, Caio. Formação do Brasil contemporâneo: colônia. São Paulo: Brasiliense; Publifolha, 2000.

RUSSELL - WOOD, A. J. R. Escravos e libertos no Brasil Colonial. Tradução de Maria Beatriz de Medina. Rio de Janeiro: Civilização Brasileira, 2005.

SANTIAGO, Nestor Eduardo Araruna; MAIA, Maurílio Casas. O garantismo penal, o encarcerado vulnerável e a intervenção da Defensoria Pública na execução penal: custos vulnerabilis? Revista Brasileira de Ciências Criminais, São Paulo, v. 152, a. 27, p. 173209, fev. 2019.

SUXBERGER, Antonio Henrique Graciano; AMARAL, Marianne Gomes de. A execução provisória da pena e sua compatibilidade com a presunção de inocência como decorrência do sistema acusatório. Revista de Direito Brasileira, São Paulo, v. 16, n. 7, p. 186-210, jan./abr. 2017.

VIANNA, Francisco José de Oliveira. Populações meridionais do Brasil: populações rurais do centro-sul. In: SANTIAGO, Silviano (coord.). Intérpretes do Brasil. 2. ed. Rio de Janeiro: Nova Aguilar, 2002. v. 1. p. 897-1.188. 